\title{
KAJIAN AWAL VALUE CHAIN RUMPUT LAUT Eucheuma cottonii DI KABUPATEN PANGKEP, SULAWESI SELATAN
}

\author{
Maharani Yulisti, Risna Yusuf dan Hikmah \\ Balai Besar Penelitian Sosial Ekonomi Kelautan dan Perikanan \\ JI. KS. Tubun Petamburan VI Jakarta 10260 \\ Telp. (021) 53650162, Fax. (021) 53650159 \\ Diterima 28 Februari 2012 - Disetujui 4 Juni 2012
}

\begin{abstract}
ABSTRAK
Penelitian bertujuan untuk menganalisis value chain usaha budidaya rumput laut (Eucheuma cottonii) di Kabupaten Pangkep, sebagai lokasi program Minapolitan Kementerian Kelautan dan Perikanan, telah dilakukan pada tahun 2011. Pengumpulan data dilakukan dengan menggunakan metode snowball sampling pada kelompok petambak pedagang pengumpul kecil, pedagang pengumpul besar dan pengolah rumput laut. Hasilnya dianalisis menggunakan metode statistik deskriptif. Hasil penelitian menunjukkan rantai pemasaran rumput laut di Pangkep cukup panjang. Pedagang pengumpul kecil dan besar memiliki peranan yang penting dalam rantai, namun mereka tidak memberikan nilai tambah pada produk tersebut. Pelaku usaha yang memperoleh keuntungan paling tinggi adalah pengumpul besar yaitu Rp. 88.660.000,per tahun dengan value added Rp. 280,- per kilo, sedangkan yang memperoleh pendapatan paling rendah adalah pengumpul kecil yaitu Rp. 5.500.000,- per tahun dengan value added Rp. 42,- per kilo. Pembudidaya mendapat keuntungan Rp. 29.075.000,- per tahun dengan value added Rp. 2.516,- per kilo. Pedagang pengumpul hanya memberikan fungsi sebagai distribusi, sedangkan petambak harus menyediakan sarana dan prasarana budidaya sehingga memiliki resiko yang cukup tinggi.
\end{abstract}

Kata Kunci: Pangkep, rumput laut, rantai nilai

\section{Abstract : Value Chain Initial Study of Seaweed (Eucheuma cottonii) at Pangkep Regency, South Sulawesi. By : Maharani Yulisti, Risna Yusuf and Hikmah.}

This research was condunctea to analyzed the value chain of Eucheuma Cottonii has been done at the Pangkep District, as one of MMAF Minapolitan Program sites in 2011. Respondents consisted of farmers, small traders, large traders and processors seaweed were chosen using snowball sampling method and analyzed using descriptive statistics methods. The results showed that the seaweed in Pangkep marketing has a long chain. Small and large traders have a prominent role in the chain, but they do not add value to the product. Entrepreneurs who earn the highest profits are big collectors of Rp. 88,660,000, - per year with a value added of Rp. 280, - per kilo, while most low income is a small collection of Rp. 5,500,000, - per year with a value added of Rp. 42, - per kilo. Farmers benefit from Rp. 29,075,000, - per year with a value added of Rp. 2,516, - per kilo. Traders only give the distribution function, while the farmers have to provide the facilities and infrastructure that farming has a high enough risk.

Keywords: Pangkep, seaweed, value chain 


\section{PENDAHULUAN}

Indonesia merupakan negara maritim dengan tiga perempat wilayahnya berupa lautan. Luas laut Indonesia lebih kurang 5.8 juta $\mathrm{km}^{2}$, garis pantai sepanjang $95.181 \mathrm{~km}$ terpanjang kedua di dunia serta jumlah pulau 17.504 menyimpan potensi sumber daya perikanan yang cukup besar baik dari segi kuantitas maupun diversitas. Sumber daya yang melimpah ini menjadikan Indonesia memiliki keunggulan komparatif (comparative advantage) di sektor kelautan dan perikanan. Oleh karena itu, Kementerian Kelautan dan Perikanan (KKP) menetapkan visinya yaitu "Indonesia Penghasil Produk Kelautan dan Perikanan Terbesar 2015", dengan misi untuk meningkatkan kesejahteraan masyarakat kelautan dan perikanan (KKP, 2010). Visi dan Misi KKP dalam Renstra 2010-2014, diterjemahkan lebih lanjut melalui berbagai program pembangunan Kelautan dan Perikanan. Target peningkatan produksi kelautan dan perikanan sampai dengan tahun 2015 dicanangkan sebesar $353 \%$. Peningkatan produksi ikan tersebut, akan diperoleh melalui peningkatan kegiatan usaha dari sektor budidaya dan penangkapan ikan. Peningkatan produksi perikanan budidaya merupakan andalan untuk dapat mewujudkan visi tersebut. Komoditas prioritas perikanan budidaya yang menjadi target dari peningkatan produksi diantaranya komoditas rumput laut. Peningkatan produksi komoditas tersebut diharapkan mampu memenuhi kebutuhan dalam negeri serta meningkatkan ekspor.

Data statistik Ditjen Perikanan Budidaya KKP Tahun 2010 menunjukkan bahwa produksi rumput laut Indonesia meningkat 32\% dari 2,96 juta ton pada tahun 2010 menjadi 3,9 juta ton pada tahun 2010. Peningkatan produksi ini harus didukung dengan sistem distribusi dan pemasaran yang baik sehingga terjadi distribusi nilai tambah yang lebih adil dalam pemasaran produk perikanan.

Pembangunan sektor perikanan di Indonesia saat ini masih dicirikan dengan tidak adanya hubungan fungsional diantara tingkatan dan pelaku usaha. Pelaku pemasaran (sektor hilir) cenderung mementingkan diri sendiri dan bersifat eksploitatif. Jaringan perikanan hanya diikat dan dikoordinasi oleh mekanisme pasar. Terdapat tiga masalah utama pada sisi pasar perikanan yaitu (1) rendahnya diversifikasi komoditi baik bahan baku maupun bahan olahan; (2) rendahnya penguasaan terhadap pasar yang disebabkan oleh kurangnya intelejensi, strategi dan promosi pasar; (3) distorsi pasar yang menyebabkan tidak berjalannya mekanisme pasar dan mendongkrak ongkos produksi. Distorsi pasar juga mengakibatkan harga komoditi di bawah harga yang semestinya (under value), margin produksi jauh lebih kecil dari margin pasar sehingga terjadi kecenderungan orang hanya berusaha hanya di sektor perdagangan.

Persaingan bisnis yang semakin ketat sebagai dampak diberlakukannya era perdagangan bebas telah menggeser paradigma bisnis dari Comparative Advantage menjadi Competitive Advantage, yang memaksa kegiatan bisnis/perusahaan memilih strategi yang tepat. Strategi yang dimaksud adalah dimana perusahaan berada dalam posisi strategis dan bisa beradaptasi dengan lingkungan yang terus berubah. Hal ini berlaku prinsip going concern yang secara umum merupakan tujuan didirikannya suatu entitas bisnis.

Value chain management merupakan semua kegiatan yang dilakukan dalam mengubah bahan baku menjadi produk yang dijual dan dikonsumsi. Ini mencakup pengertian bahwa ada nilai tambah pada setiap titik dalam rantai. Di pasar modern pengelolaan yang cermat dari keseluruhan nilai atau rantai pasok adalah penting untuk memastikan kualitas dan keselamatan dan untuk memaksimalkan efisiensi. Analisis value chain dilakukan untuk menilai semua kegiatan dan stakeholder serta hubungannya dalam rantai pasok, dengan tujuan membantu untuk menengahi inefisiensi seperti variabilitas, mengurangi kerentanan dan meningkatkan kapasitas untuk beradaptasi dengan perubahan (Vermulen et al., 2008).

Berdasarkan deskripsi permasalahan di atas maka suatu kajian value chain untuk melihat hubungan antara pelaku pemasaran produk perikanan menarik untuk dilakukan. Dengan tersedianya gambaran yang jelas 
maka dapat dilakukan beberapa upaya untuk memperbaiki sistem pemasaran produk perikanan sehingga dapat terjadi distribusi nilai tambah yang lebih adil dalam pemasaran produk perikanan. Tujuan dari penelitian ini adalah untuk mengetahui besarnya nilai tambah, distribusi serta mengetahui pelaku usaha dan perannya di sepanjang rantai nilai Kabupaten Pangkep.

\section{METODE PENELITIAN}

\section{Lokasi dan Waktu Penelitian}

Penentuan daerah penelitian ini dilakukan secara sengaja atau purposive, yaitu di Kabupaten Pangkajene Kepulauan (Kabupaten Pangkep) dengan mengambil sampel pada lokasi minapolitan di Kabupaten Pangkep serta daerah-daerah yang menjadi wilayah distribusi dan pemasaran rumput laut. Kabupaten Pangkep dipilih menjadi lokasi penelitian karena merupakan salah satu lokasi minapolitan di Indonesia dengan komoditas rumput laut Eucheuma cottonii.

Penelitian dilaksanakan dangan metode multi-stage cluster sampling yaitu sampel digambarkan dalam beberapa tahap yang melibatkan beberapa unit sampel. Metode ini menggambarkan bahwa pada setiap pengambilan sampel primer tahap pertama, dapat menggambarkan kemungkinan dari pengambilan sampel tahap kedua. Pengambilan sampel tahap ketiga dapat dilakukan berdasarkan dari pengambilan sampel tahap kedua, dan selanjutnya sampai pengambilan sampel tahap akhir didapatkan dari perincian untuk unit sampel pada setiap tahap tersebut. Metode ini digunakan dalam memilih sampel dalam perkotaan, setengah perkotaan, dan studi untuk lokasi geografi pedesaan (Sekaran, 2000). Penelitian ini mengambil sampel di Kecamatan Labakkang, Kecamatan Mandalle, Kecamatan Segeri, Kabupaten Maros, dan Kota Makasar. Ketiga kecamatan tersebut dipilih karena merupakan lokasi minapolitan di Kabupaten Pangkep. Kabupaten Maros merupakan lokasi pabrik pengolahan rumput laut, dan Kota Makasar merupakan lokasi perusahaan distribusi rumput laut untuk pasar ekspor. Berdasarkan arus aliran komoditi tersebut, maka ditelusuri mulai dari agen sarana produksi rumput laut, pembudidaya rumput laut, pedagang pengumpul, pedagang besar, sampai dengan perusahaan pengolahan rumput laut. Penelitian dilakukan pada bulan April sampai dengan bulan November 2011.

\section{Pengumpulan Data}

Penelitian ini menggunakan pendekatan pemahaman pedesaan dalam waktu cepat, dengan melakukan pengumpulan data pokok dan informasi kualitatif tentang rumput laut secara komprehensif. Pengumpulan informasi tersebut dilakukan dengan secara sistematis dan berlapis dari tingkat kabupaten dan provinsi (Dinas Kelautan dan Perikanan). Responden yang dipilih terdiri dari pelaku usaha yang terkait dengan sentra produksi dan pasar perikanan, mulai dari pembudidaya rumput laut, pedagang pengumpul kecil hingga pedagang besar yang berada di lingkup pasar rumput laut. Metode untuk pengambilan responden menggunakan metode snowball sampling yakni dengan menentukan sampel awal kemudian menentukan sampel berikutnya berdasarkan informasi yang diperoleh.

\section{Analisa Data}

Analisa data yang digunakan pada riset ini adalah deskriptif kualitatif dan kuantitatif. Analisis deskriptif kualitatif menjelaskan kondisi sentra produksi dan pasar yang ada, sedangkan analisis kuantitatif dilakukan untuk perhitungan analisis usaha perikanan pada setiap pelaku usaha rumput laut mulai dari produksi hingga pemasaran. Pada analisis ini akan dilihat seberapa besar pendapatan usaha budidaya dan pemasaran rumput laut berdasarkan harga penjualan yang diterima oleh pelaku usaha tersebut.

\section{HASIL DAN PEMBAHASAN}

\section{Kondisi Umum Perikanan Kabupaten Pangkep}

Arahan pengembangan komoditas unggulan Kawasan Minapolitan Kabupaten Pangkep saat ini mengacu pada potensi dan kondisi pemanfaatan yang menghasilkan 
produk yang dominan untuk dikembangkan yaitu komoditas udang windu, ikan bandeng dan rumput laut Eucheuma cotonii. Komoditas rumput laut Eucheuma cottonii merupakan hasil produksi budidaya laut. Potensi pengembangan kawasan budidaya di Kabupaten Pangkep pada areal pertambakan yaitu sebesar $13.494,8$ ha, sedangkan potensi pada areal perairan laut sebesar 7.900 ha. Potensi luasan lahan yang dimanfaatkan baru mencapai sekitar 10.755,47 ha untuk budidaya dan hanya $1.421,80$ ha untuk kegiatan budidaya laut.

Produksi rumput laut Eucheuma cottonii di Kabupaten Pangkep meningkat setiap tahunnya. Pada tahun 2007 terjadi peningkatan produksi yang tajam dibanding tahun sebelumnya, namun menurun pada tahun 2008 meskipun tidak begitu signifikan. Pada tahun 2008-2009 terjadi stabilitas produksi meskipun kondisi produksi mengalami penurunan. Peningkatan nilai produksi terjadi pada tahun 2007 yang terjadi karena lonjakan produksi rumput laut. Namun yang lebih mengejutkan adalah peningkatan nilai produksi yang sangat tajam di tahun 2008 yaitu sebesar 2.064\% dibanding tahun 2006 meskipun produksi rumput laut menurun dibanding tahun sebelumnya. Sampai dengan tahun 2010, peningkatan produksi rumput laut sebesar 761\% dibanding tahun 2006, dengan peningkatan nilai produksi sebesar $2.607 \%$. Hasil produksi komoditas rumput laut
Eucheuma Cottonii dengan kondisi luasan pemanfaatan yang ada dapat dilihat pada Tabel 1.

\section{Pemetaan Value Chain Rumput Laut di Kabupaten Pangkep}

Kunci untuk menganalisis rantai nilai adalah dengan memahami kegiatan pada setiap pelaku usaha dan kemudian mengelola kegiatan tersebut agar produk menjadi lebih baik sehingga lebih kompetitif dan berdaya saing. Selama ini, usaha rumput laut mulai proses produksi hingga pemasaran memiliki rantai yang panjang sehingga harga jual akhir yang tinggi. Hal ini menyebabkan produk tidak kompetitif dan tidak berdaya saing. Analisis rantai nilai merupakan sarana untuk memeriksa setiap proses yang dilakukan dalam sebuah sistem untuk menciptakan produk dan mengidentifikasi kegiatan dari setiap pelaku usaha.

Tujuan dari aktivitas pemetaan value chain ini adalah untuk membangun pemahaman mengenai struktur pasar pada tingkat pembudidaya dan pelaku usaha lainnya baik dalam pengolahan maupun pemasaran. Peta value chain menunjukkan arus produk, pelaku usaha kunci dan proses penambahan nilai (value added) dalam rantai, untuk meyakinkan bahwa tidak ada satupun yang terlewatkan. Peta dasar value chain rumput laut di Kabupaten Pangkep dapat dilihat pada Gambar 1.

Tabel 1. Produksi Budidaya Rumput Laut Eucheuma cottonii di Kabupaten Pangkep, Tahun 2005 - 2010.

Table 1. Production of Seaweed Eucheuma cottonii at Pangkep Regency, 2005-2010.

\begin{tabular}{ccc}
\hline Tahun/Year & $\begin{array}{c}\text { Produksi Kering (Ton)/ } \\
\text { Dried Product (Tonnes) }\end{array}$ & $\begin{array}{c}\text { Nilai ( Rp 000 )/ } \\
\text { Value (IDR , 000) }\end{array}$ \\
\hline 2005 & 974.0 & $3,409,000$ \\
2006 & $2,490.0$ & $8,715,000$ \\
2007 & $8,248.0$ & $28,868,000$ \\
2008 & $7,286.6$ & $87,439,200$ \\
2009 & $7,148.7$ & $64,338,300$ \\
2010 & $8,391.40$ & $92,305,950$ \\
\hline
\end{tabular}

Sumber: Dinas Kelautan dan Perikanan Kabupaten Pangkep, 2011

Source: Marine and Fisheries Service of the Pangkep Regency, 2011 


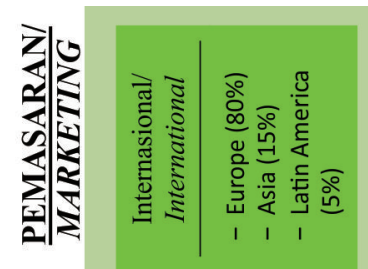

$\uparrow$
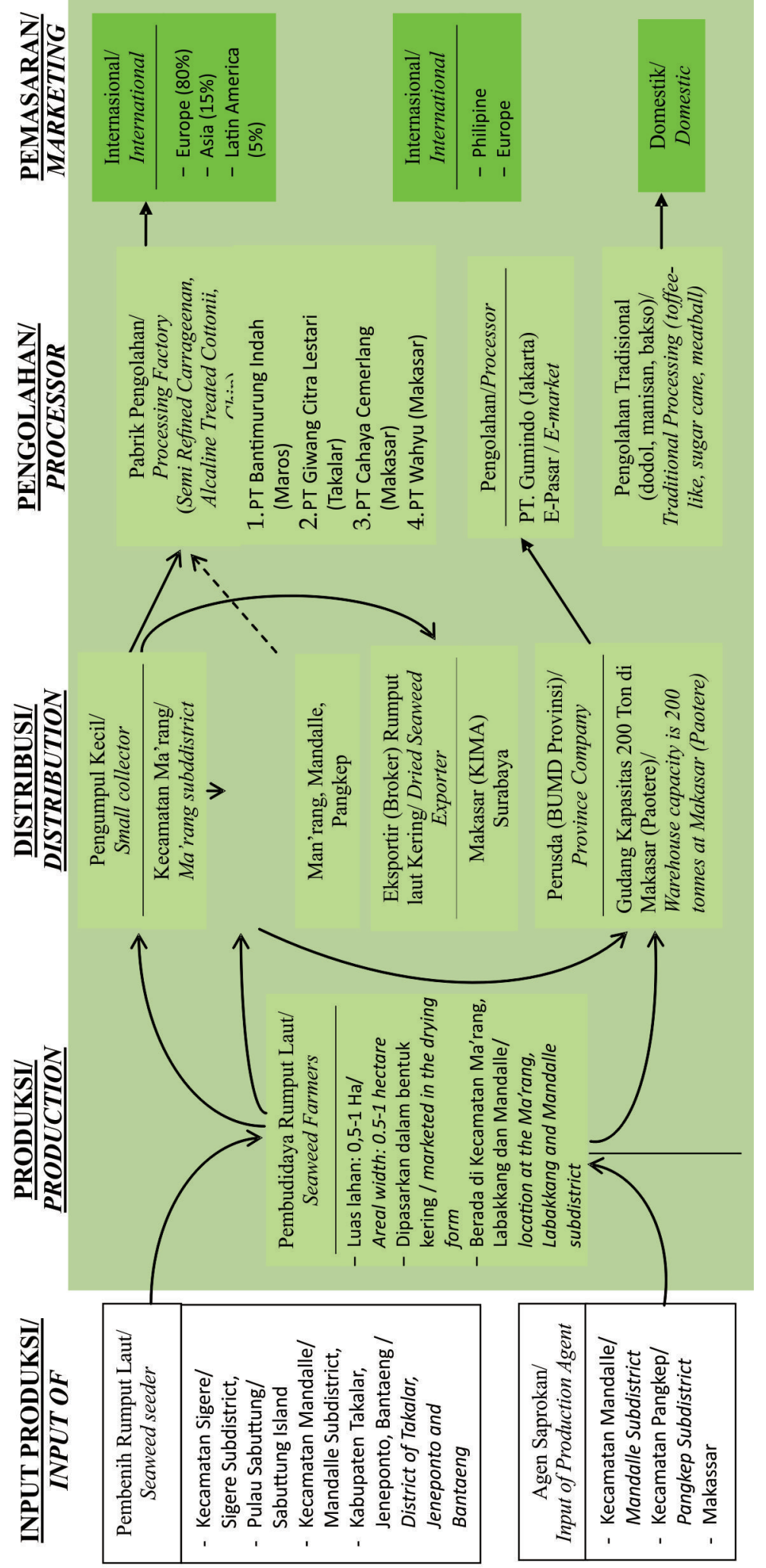

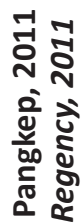

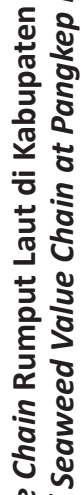

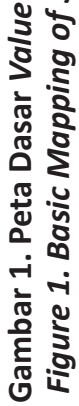


Rantai nilai (value chain) rumput laut di Kabupaten Pangkep dapat dilihat dari beberapa tahap yaitu pra produksi, produksi, distribusi, pengolahan dan konsumen akhir. Pada tahap pra produksi, komoditas rumput laut di Kabupaten Pangkep memerlukan benih dan saprokan untuk membantu produksi rumput laut. Benih rumput laut berasal dari berasal dari Kecamatan Sigere, Pulau Sabuttung, Kecamatan Mandalle, Kecamatan Bantaeng dan Kabupaten Takalar. Sarana produksi rumput laut (Saprokan) didapatkan pembudidaya dari Kecamatan Mandalle, Kecamatan Ma'rang dan Makassar. Saprokan tersebut diantaranya tali tambang dan tali ris untuk mengikat rumput laut.

Pembudidaya rumput laut yang ada di Kabupaten Pangkep tersebar di Kecamatan Ma'rang, Kecamatan Labakkang dan Kecamatan Mandalle dengan rata-rata luas lahan yang dimiliki 0,5-1 Ha. Budidaya rumput laut yang dilakukan di Kabupaten Pangkep ini menggunakan teknologi longline yaitu pembudidayaan rumput laut di kolom air (eupotik) dekat permukaan perairan laut dengan menggunakan tali yang dibentangkan dari satu titik ke titik lain dengan panjang $25-30 \mathrm{~m}$, dalam bentuk terangkai berbentuk segi empat dengan bantuan pelampung dan jangkar sesuai dengan SNI 7579.3:2010 (Ditjen Perikanan Budidaya, 2011). Di Kabupaten Pangkep, satu unit longline rata-rata terdiri dari 100 bentang tali yang berukuran 25 meter yang diikat pada beberapa jangkar berupa kayu atau bambu panjang.

Dalam teknisnya, budidaya rumput laut dibantu oleh tenaga kerja pengikat tali ris dan tenaga kerja pengikat rumput laut ke tali/tambang. Tenaga kerja tersebut dapat berupa tenaga kerja lepas atau bahkan pembudidaya itu sendiri yang mengerjakannya. Harga upah rata-rata untuk tenaga tersebut adalah Rp. 2.500,-/bentang/orang. Rata-rata pengikatan bibit rumput laut yang dibutuhkan untuk satu bentang tali adalah $7 \mathrm{~kg}$, dimana akan menghasilkan $70 \mathrm{~kg}$ rumput laut basah setiap bentangnya. Budidaya rumput laut ini memerlukan waktu 2 bulan agar rumput laut besar dan bisa dipanen sesuai dengan kebutuhan pasar. Rata-rata panen rumput laut sebanyak lima kali dalam setahun.

Rumput laut yang diproduksi oleh pembudidaya umumnya dijual dalam bentuk kering. pembudidaya melakukan pengeringan terhadap rumput laut dengan dijemur di bawah matahari sehingga menghasilkan rendemen sekitar $1 / 6$ dari berat awal. Penjualan dilakukan ke pedagang pengumpul kecil yang ada di sekitarnya (Desa Tamarupa, Kecamatan Mandalle). Pedagang pengumpul kecil ini umumnya yang mengambil atau menjemput rumput laut ke pembudidaya dengan menggunakan motor yang kemudian ditampung di sebuah gudang untuk kemudian dijual ke pengumpul besar dalam satu kabupaten. Rumput laut tersebut kemudian didistribusikan ke penampung gudang di Makassar dan perusahaan di Kompleks Industri Makasar (KIMA) yang ada di Makassar. Dari penampung gudang ini rumput laut hanya ditampung untuk sementara waktu. Rumput laut yang ada di penampungan gudang ini biasanya langsung di ekspor ke Philipina dan China. Perusahaanperusahaan yang merupakan pabrik pengolahan rumput laut yang ada di Sulawesi Selatan yaitu: (1) PT Bantimurung Indah berlokasi di Maros; (2) PT Giwang Citra Lestari berlokasi di Takalar; (3) PT Cahaya Cemerlang yang berlokasi di Makasar; dan (4) PT Wahyu berlokasi di Makasar. Perusahaan-perusahaan ini biasa memasarkan produk olahan rumput laut dalam bentuk SRC, ATC dan Chip. Adapun negara yang menjadi tujuan ekspor perusahaan ini adalah Eropa (80\%) dalam bentuk powder, Asia (15\%) khususnya Jepang dalam bentuk Chip dan Amerika Latin (5\%) dalam bentuk bahan baku.

Selain dijual ke pedagang kecil, rumput laut juga dijual ke perusahaan daerah (Perusda) yaitu sebuah perusahaan milik pemerintah daerah Provinsi Sulawesi Selatan yang berbentuk Badan Usaha Milik Daerah (BUMD). Perusahaan ini baru menjalankan usaha rumput laut pada bulan April tahun 2011. Perusda ini sebagian besar menerima rumput laut dari pengumpul (60\%) dan sisanya dari petani. 


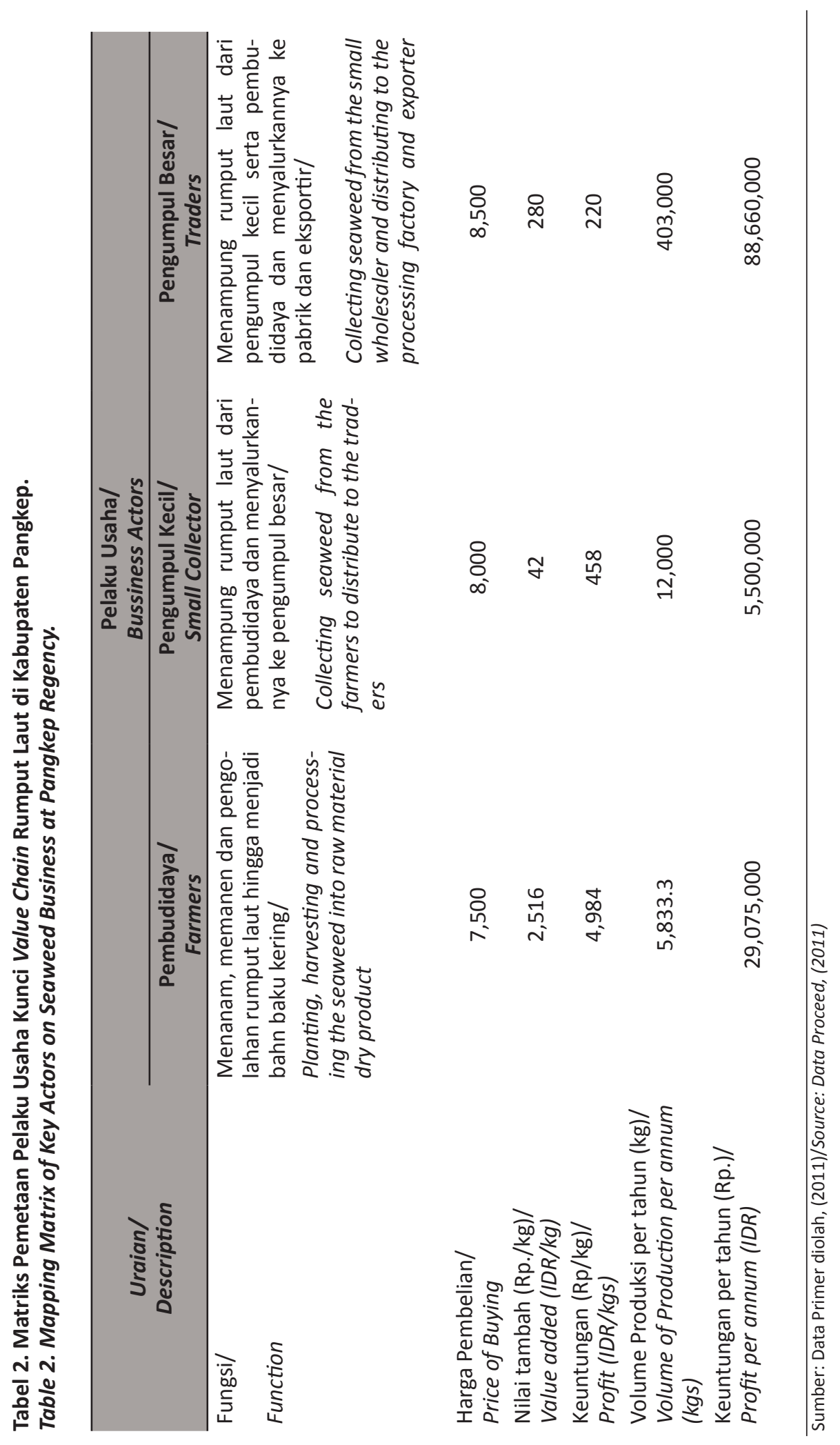


Pengumpul yang menjual rumpul laut ke Perusda itu sebagian besar berasal dari Kabupaten Palopo (50\%), Kabupaten Pangkep (20\%) dan sisanya dari daerah lainnya. Perusahaaan ini memiliki gudang yang berada di Paotere, Kota Makassar yang dapat menampung rumput laut dengan kapasitas 200 ton. Rumput laut yang dimiliki oleh Perusda ini semuanya (100\%) dijual ke PT GUMINDO di Jakarta dan e-pasar.

Rumput laut yang berasal dari pembudidaya juga dijual ke koperasi yang anggotanya sebagian besar wanita. Bahan baku rumput laut tersebut kemudian diolah secara tradisional menjadi dodol, manisan dan bakso rumput laut. Produk olahan rumput laut ini diproduksi untuk memenuhi konsumen pasar sekitarnya saja.

Seperti dikemukakan pada rantai nilai di atas dimana komoditas rumput laut memiliki beberapa tahapan mulai dari pra produksi, produksi, distribusi, pengolahan dan pemasaran. Pada masing-masing tahapan ini terdiri dari beberapa pelaku utama yaitu pada tahapan pra produksi adalah pembibitan dan penjual sarana produksi perikanan (saprokan). Masingmasing pelaku utama ini memiliki fungsi yaitu pembibit memiliki fungsi sebagai penyedia bibit rumput laut, sedangkan penjual saprokan berfungsi sebagai penyedia sarana produksi rumput laut seperti tambang, tali ris dan pelampung. Kedua pelaku utama ini memiliki tujuan yang sama yaitu mendapatkan keuntungan. Nilai yang diperoleh dari pembibitan adalah berupa bibit yang siap tanam sedangkan nilai yang didapatkan dari penjual saprokan adalah penyediaan saprokan. Keuntungan yang didapat untuk usaha pembibitan ini sebesar Rp 400,-/ kg, sedangkan profit dari usaha penjualan saprokan sebesar Rp. 160/kg. Permasalahan yang ada dalam pra produksi baik pembibitan maupun penjualan saprokan adalah input produksi ini masih didapatkan dari luar Kabupaten Pangkep. Untuk bibit rumput laut itu sendiri masih didatangkan dari Kabupaten lain seperti Kabupaten Maros, Kabupaten
Takalar dan Kabupaten Barru, sedangkan untuk saprokan seperti tambang, tali masih dari Makassar.

Pada tahap produksi, pelaku utama yang terlibat yaitu pembudidaya, tenaga kerja pengikat tali ris dan tenaga kerja pengikat bibit. Pembudidaya ini berfungsi untuk menanam dan memanen rumput laut, sedangkan untuk tenaga kerjanya, sebagai pengikat tali ris berfungsi untuk mengikat alat sebagai tempat untuk budidaya rumput laut, selanjutnya tenaga kerja pengikat bibit memiliki fungsi untuk mengikat bibit rumput laut. Ketiga pelaku utama ini memiliki tujuan untuk mendapatkan keuntungan bagi pembudidaya, sedangkan dua pelaku lainnya bertujuan untuk mendapatkan upah. Nilai yang diperoleh dari pembudidaya adalah pembesaran dan pengeringan rumput laut, sedangkan untuk tenaga kerja pengikat tali ris dan tenaga kerja oengikat bibit masing-masing memiliki nilai yaitu sarana produksi yang siap pakai dan rumput laut yang siap tanam. Untuk profit, dari pembudidaya diperoleh profit sebesar Rp 200-300/kg, sedangkan tenaga kerja pengikat tali ris dan pengikat bibit masingmasing memperoleh profit sebesar Rp 2.000-2.500/bentang per orang dan Rp 2.000-2.500/bentang per orang. Permasalahan pada produksi ini adalah pada musim kemarau salinitas tinggi, benih dipakai berkali-kali selama setahun, kurangnya informasi pasar.

Selanjutnya, pada tahap distribusi pelaku utama yang terlibat adalah pengumpul kecil, pengumpul besar, penampung gudang (broker) dan Pusda. Masing-masing pelaku utama ini memiliki fungsi yaitu: pengumpul kecil berfungsi menampung rumput laut dari pembudidaya dan menyalurkannya ke pengumpul besar, pengumpul besar berfungsi menampung rumput laut dari pengumpul kecil serta pembudidaya dan menyalurkan ke pabrik dan eksportir, penampung gudang (broker) memiliki fungsi sebagai pengumpul bahan baku rumput laut dari pengumpul untuk 
diekspor dalam bentuk kering dan Pusda berfungsi untuk mengumpulkan bahan baku rumput laut dari pengumpul dan pembudidaya untuk dipasarkan dalam bentuk kering. Tiga pelaku utama (pengumpul kecil, pengumpul besar dan penampung gudang) memiliki tujuan yang sama yaitu mendapatkan keuntungan, sedangkan Pusda yang merupakan perusahaan miliki pemerintah Sulawesi Selatan memiliki tujuan untuk menstabilkan harga dan profit. Nilai yang diperoleh dari keempat pelaku utama pada tahapan distribusi ini adalah menyalurkan (distribusi) rumput laut, melakukan proses packaging yang selanjutnya dipasarkan. Profit yang diperoleh dari masing-masing pelaku utama ini bervariasi. Untuk pedagang kecil profit yang didapat sebesar $\mathrm{Rp} 500 / \mathrm{kg}$, untuk pedagang besar Rp 300-700/kg, penampung gudang sebesar Rp 400/kg dan Pusda berkisar antara
Rp 400-500/kg. Permasalahan yang ada pada pelaku utama ini adalah ketidaktahuan mereka tentang harga di pasar eksportir.

Pada tahap pengolahan pelaku utamanya adalah pabrik pengolahan rumput laut dan pengolahan rumput laut tradisional. Pabrik pengolahan rumput laut mengolah rumput laut menjadi produk setengah jadi yaitu Semi Refine Carrageenan (SRC), Alcali Treated Cottonii (ATC) dan Chip (pabrik pengolahan). Pengolah rumput laut tradisional mengolah rumput laut menjadi makanan siap konsumsi seperti dodol, manisan dan bakso rumput laut.

Kedua pelaku utama ini memiliki tujuan yang sama yaitu mendapatkan profit. Namun bagi pengolah tradisional, disamping untuk mendapatkan profit juga diharapkan sebagai wadah untuk memberdayakan masyarakat di sekitarnya.

Tabel 3. Isu Kunci Pada Setiap Pelaku Usaha Budidaya Rumput Laut di Kabupaten Pangkep. Table 3. Key Issues in Every Business Actor of Seaweed Farming at Pangkep Regency.

\begin{tabular}{|c|c|}
\hline $\begin{array}{l}\text { Pelaku Usaha/ } \\
\text { Business Actors }\end{array}$ & $\begin{array}{l}\text { Isu Kunci/ } \\
\text { Key Issues }\end{array}$ \\
\hline $\begin{array}{l}\text { Pembudidaya rumput laut/ } \\
\text { Seaweed farmers }\end{array}$ & $\begin{array}{l}\text { - Akses terhadap pasar, teknologi, input produksi, dan jasa/ } \\
\text { Access to the market, technology, input of production and } \\
\text { services } \\
\text { - } \text { Lemahnya posisi tawar/ Weaknesses of bargaining position } \\
\text { - Kompetisi dengan pembudidaya besar (pengusaha)/ } \\
\text { Competition with the large farmer (businessmen) } \\
\text { - Kurangnya informasi pasar/ Lack of market information }\end{array}$ \\
\hline $\begin{array}{l}\text { Pengumpul kecil/ } \\
\text { Small collectors }\end{array}$ & $\begin{array}{l}\text { - Keterkaitan antara pembudidaya dengan pengumpul/ } \\
\text { Linkages between farmers and collectors }\end{array}$ \\
\hline $\begin{array}{l}\text { Pengumpul besar/ } \\
\text { Traders }\end{array}$ & $\begin{array}{l}\text { - Tidak mengetahui harga di eksportir/ Do not have } \\
\text { information of price at exporter }\end{array}$ \\
\hline $\begin{array}{l}\text { Pengolah/ } \\
\text { Processor }\end{array}$ & $\begin{array}{l}\text { - Kompetisi (lokal dan global/internasional)/ Competition } \\
\text { (local and global/international) }\end{array}$ \\
\hline $\begin{array}{l}\text { Pengekspor/ } \\
\text { Exporter }\end{array}$ & $\begin{array}{l}\text { - Logistik/logistic } \\
\text { - Pengelolaan rantai nilai/Supply chain management }\end{array}$ \\
\hline $\begin{array}{l}\text { Konsumen/ } \\
\text { Consument }\end{array}$ & $\begin{array}{ll}\text { - } & \text { Keamanan pangan/ Food safety } \\
\text { - } & \text { Harga/Price } \\
\text { - } & \text { Konsistensi keberlanjutan produk/ Consistency of product } \\
& \text { simultaneously }\end{array}$ \\
\hline
\end{tabular}

Sumber: Data Primer diolah, (2011)/Source: Data Proceed, (2011 
Komoditas rumput laut yang ada di Kabupaten Pangkep ini memiliki banyak permasalahan yang merupakan isu kunci yang timbul di setiap pelaku utama. Untuk pembudidaya masalah yang ada diantaranya akses terhadap pasar, teknologi, input produksi, dan jasa, lemahnya posisi tawar, kompetisi dengan pembudidaya besar (pengusaha) dan kurangnya informasi pasar. Pada tingkat pengumpul kecil adanya keterkaitan antara pembudidaya dengan pengumpul.

Pengumpul besar memiliki isu yang dihadapi yaitu tidak mengetahui harga di eksportir sehingga hal ini menyulitkan pengumpul besar dalam menentukan harga pada tingkat pengumpul kecil dan pembudidaya. Yang menjadi isu pada pengolah adalah persaingan baik di tingkat domestik dan pasar internasional. Di pasar domestik, belum terbukanya akses pasar dan market share di pasar ini relatif kecil. Sedangkan untuk pasar internasional, yang menjadi isu adalah disamping persaingan dengan negara lain juga dari sisi non tarif barier yaitu dari sisi kualitas rumput laut yang sesuai dengan standar internasional. Pada tahap pengekspor yang menjadi isu utama adalah logistik dan SCM (supply chain management) dimana kedua isu ini berkaitan dengan efektivitas dan efisiensi produk olahan rumput laut. Terakhir adalah tingkat konsumen yang merupakan pengguna akhir produk olahan rumput laut laut ini. Isu penting yang harus diperhatikan pada pelaku usaha ini adalah keamanan pangan produk rumput laut, sisi harga dan konsistensi keberlanjutan produk rumput laut ini.

\section{KESIMPULAN DAN IMPLIKASI KEBIJAKAN}

Pemasaran produk perikanan pada era globalisasi ini sangat dinamis. Perubahan yang sangat cepat dalam produksi (budidaya ikan), pengolahan, dan pemasaran serta pasokan input budidaya juga sarana produksi ikan mempengaruhi seluruh titik pada rantai nilai, dari produsen ke konsumen.
Rumput laut merupakan produk ekspor, dan biasanya diekspor dalam bentuk raw material rumput laut kering.

Pada rantai pemasarannya, rumput laut di Pangkep memiliki rantai yang cukup panjang. Pedagang pengumpul kecil dan besar memiliki peranan yang penting dalam rantai, namun mereka tidak memberikan proses nilai tambah yang signifikan pada produk tersebut. Inefisiensi terjadi bila pada satu titik rantai tidak memberikan nilai tambah pada produk tersebut namun memberikan penambahan harga pada produknya sehingga produk kurang berdaya saing. Pedagang pengumpul hanya mendistribusikan rumput laut dari lokasi budidaya ke pedagang eksportir. Pembudidaya tidak memiliki akses selain kepada pedagang pengumpul tersebut sehingga mereka tidak memiliki posisi tawar dalam penetapan harga.

Pelaku usaha yang memiliki posisi tawar paling kuat dalam rantai nilai rumput laut di Pangkep adalah pedagang eksportir, sedangkan yang paling lemah adalah pembudidaya rumput laut. Pengelolaan rantai nilai antara pemasok saprokan dan produk rumput laut dengan konsumen adalah market. Dalam rantai nilai, pedagang pengumpul berperan memasok sarana produksi ikan, sementara budidaya rumput laut dilakukan oleh pembudidaya. Pelaku usaha yang memperoleh pendapatan paling rendah adalah pembudidaya (Rp 200 s.d. Rp 300/kg rumput laut kering), sedangkan yang memperoleh pendapatan paling tinggi adalah pedagang pengumpul besar (Rp 300 s.d. Rp 700/kg rumput laut kering).

Peningkatan rantai nilai dapat dilakukan dengan:

a. mengoptimalkan produksi rumput laut, mengembangkan produksi bibit rumput laut di Kepulauan Pangkep, meningkatkan kualitas rumput laut, dan memperkuat manajemen usaha budidaya rumput laut. 
b. mengkonversi produk rumput di tingkat pembudidaya dari produk kering menjadi produk olahan (ATC dan SRC) untuk diekspor.

c. membentuk kluster rumput laut yang diinisiasi dari pembudidaya.

d. meningkatkan edukasi pada masyarakat tentang fungsi rumput laut baik sebagai makanan sehat, bahan baku kosmetik, dan bahan tambahan makanan yang aman untuk dikonsumsi. Selain itu juga mengembangkan strategi bisnis rumput laut olahan.

\section{DAFTAR PUSTAKA}

Badan Perencanaan Pembangunan Daerah (Bappeda) Kabupaten Pangkajene Kepulauan. 2010. Laporan Akhir Kabupaten Pangkajene Kepulauan.

Badan Perencanaan Pembangunan Daerah (Bappeda) Kabupaten Pangkajene Kepulauan. 2010. Master plan Kawasan Minapolitan, Pemerintah Kabupaten Pangkajene dan kepulauan.

Badan Perencaan Pembangunan Daerah (Bappeda) Kabupaten Pangkajene Kepulauan.Laporan Rencana Tata Ruang Wilayah (RTRW) Kabupaten Pangkajene dan Kepulauan tahun 2010-2030.
Dinas Kelautan dan Perikanan Pangkep. 2010. Keputusan Bupati Pangkajene dan Kepulauan tentang Pembentukan Kelompok Kerja Pengembangan Kawasan Minapolitan Kabupaten Pangkajene dan Kepulauan.

Dinas Kelautan dan Perikanan Pangkep. 2010. Keputusan Kepala Dinas Kelautan dan Perikanan Kabupaten Pangkajene dan Kepulauan tentang Penetapan Tim Pengembangan Kawasan Minapolitan Kabupaten Pangkajene dan Kepulauan.

Dinas Kelautan dan Perikanan Pangkep. 2010. Keputusan Bupati Pangkajene dan Kepulauan Tentang Penetapan Lokasi Kawasan Minapolitan Kabupaten Pangkajene dan Kepulauan.

Direktorat Jenderal Perikanan Budidaya, Direktorat Produksi. 2011. Petunjuk Teknis Budidaya Rumput Laut Eucheuma spp. Kementrian Kelautan dan Perikanan.

Sekaran, U. 2000. Research Methods for Business. A Skill-Building Approach.Third Edition. Southern Illiniois University at Carbonadale. John Wiley and Sons, Inc. New York.

Vermeulen, S., J. Woodhill, F. Proctor, and R. Delnoye. 2008. Chain-Wide Learning for Inclusive Agrifood Market Development. A guide to Multi-Stakeholder processes for Linking Small-scale Producers to Modern Market. IIED and CD\&IC. Wageningen University and Research Center. Netherlands. 